\title{
Hamacreadium cribbi n. sp. (Digenea: Opecoelidae) from Lethrinus miniatus (Forster) (Perciformes: Lethrinidae) from New Caledonian waters
}

\author{
Rodney A. Bray $(\mathbb{D} \cdot$ Jean-Lou Justine $\mathbb{D}$
}

Received: 29 March 2016/ Accepted: 30 July 2016

(C) The Author(s) 2016. This article is published with open access at Springerlink.com

\begin{abstract}
A new species of Hamacreadium Linton, 1910, H. cribbi n. sp. is described from Lethrinus miniatus (Forster) from the waters off New Caledonia. It is compared with the other species of Hamacreadium reported from lethrinids and is characterised by the size of its eggs which tend to be larger [72-93 (84) vs 54-81 (56) $\mu \mathrm{m}$ long] than those of other species. Other characteristics, such as body size and shape and internal ratios, differentiate $H$. cribbi from other species; these differences are discussed in detail.
\end{abstract}

\section{Introduction}

Hamacreadium Linton, 1910 is one of a group of plagioporine genera which are poorly defined morphologically and is "characterized by a combination of rather generalized plagioporine characters. Pre-eminent among those are the excretory vesicle extending into the forebody, deeply lobed ovary, distinctly

R. A. Bray $(\bowtie)$

Department of Life Sciences, Natural History Museum, Cromwell Road, London SW7 5BD, UK

e-mail: rab@nhm.ac.uk

\section{J.-L. Justine}

Institut de Systématique, Évolution, Biodiversité, ISYEB,

UMR7205 CNRS, EPHE, MNHN, UPMC, Muséum

National d'Histoire Naturelle, Sorbonne Universités, CP

51, 57 rue Cuvier, 75231 Paris Cedex 05, France submedian genital pore, and the vitelline follicles entering the forebody and extending beyond the testes to the posterior extremity' (Cribb, 2005). The opecoelids are a group in need of a thorough molecular examination, and as a start we have sequenced a variety of worms, and have found that the Hamacreadium-like species found in Lethrinus miniatus (Forster) clusters with, but is distinct from worms identified as H. mutabile Linton, 1910 (see Justine et al., 2012b; Andres et al., 2014; Bray et al., 2016). To facilitate the discussion of this species in our phylogenetic studies we here describe and name this form.

\section{Materials and methods}

Fish were collected along the external slope of the reef, off Nouméa, New Caledonia. Digeneans were collected live, immediately fixed in nearly boiling saline (Cribb \& Bray, 2010; Justine et al., 2012a) and then transferred to $80 \%$ ethanol. Whole-mounts were stained with Mayer's paracarmine, dehydrated in an ethanol series, cleared in beechwood creosote and mounted in Canada balsam. Measurements were made through a drawing tube on an Olympus BH-2 microscope, using a Digicad Plus digitising tablet and Carl Zeiss KS100 software adapted by Imaging Associates, and are quoted in micrometres. The following abbreviations are used: BMNH, British Museum (Natural History) Collection at the Natural History Museum, 
London, UK; MNHN JNC, Muséum National d'Histoire Naturelle, Paris, France.

\section{Family Opecoelidae Ozaki, 1925 Subfamily Plagioporinae Manter, 1947 Genus Hamacreadium Linton, 1910 $^{1}$}

\section{Hamacreadium cribbi $\mathbf{n}$. sp. $^{2}$}

Syns Neolebouria sp. A. of Justine et al. (2010b) in part, Hamacreadium sp. of Bray et al. (2016)

Type-host: Lethrinus miniatus (Forster) (Lethrinidae), Trumpet Emperor.

Type-locality: Récif Kué, External slope, New Caledonia $\left(22^{\circ} 34^{\prime} 892 \mathrm{~S}, 166^{\circ} 29^{\prime} 673 \mathrm{E} ; 21 . v i .2007\right)$.

Other localities: Off Ever Prosperity, external slope, depth $60 \mathrm{~m}$, New Caledonia $\left(22^{\circ} 27^{\prime} \mathrm{S}, 166^{\circ} 21^{\prime} \mathrm{E}\right.$; 22.viii.2006, 11.ix.2006, 07.xi.2006).

Type-material: Holotype: MNHN JNC2204a. Paratypes: MNHN JNC1924, 1952, 2114, 2162, 2184, 2186, 2202, 2203, 2204b, 2205, 2207, 2208, 2300, 2402, 2706, 2822B, 2824A; BMNH 2016.4.1.1-16.

Site in host: Digestive tract.

Prevalence: $83 \%$ (24 of 29).

Etymology: This species is named for our colleague Tom Cribb of the University of Queensland, the preeminent digenean taxonomist of the Indo-Pacific Region.

\section{Description (Figs. 1-2)}

[Based on 90 specimens from Lethrinus miniatus (25 measured, see Table 1)]. Body elongate, linguiform, tapering in forebody, wider in hindbody (Fig. 1). Tegument unarmed. Pre-oral lobe distinct. Oral sucker oval, subterminal. Ventral sucker rounded, in anterior third of body, distinctly larger than oral sucker. Prepharynx short, entirely dorsal to oral sucker. Pharynx oval. Oesophagus distinct. Intestinal bifurcation in mid-forebody. Caeca narrow, end blindly in posterior quarter of post-testicular region.

Testes 2, oval to rounded, smoothly irregular, contiguous or slightly separated, in mid-hindbody, oblique. Cirrus-sac large, claviform, sigmoid, much wider proximally, reaches dorsally to ventral sucker,

\footnotetext{
${ }_{1}$ http://urn:lsid:zoobank.org:act:504F5E58-7DB1-4AF7-84601514DE47DF61.

${ }^{2}$ http://urn:1sid:zoobank.org:act:CBAC6DA3-B021-4306-9D 76-3950037A8CBE
}

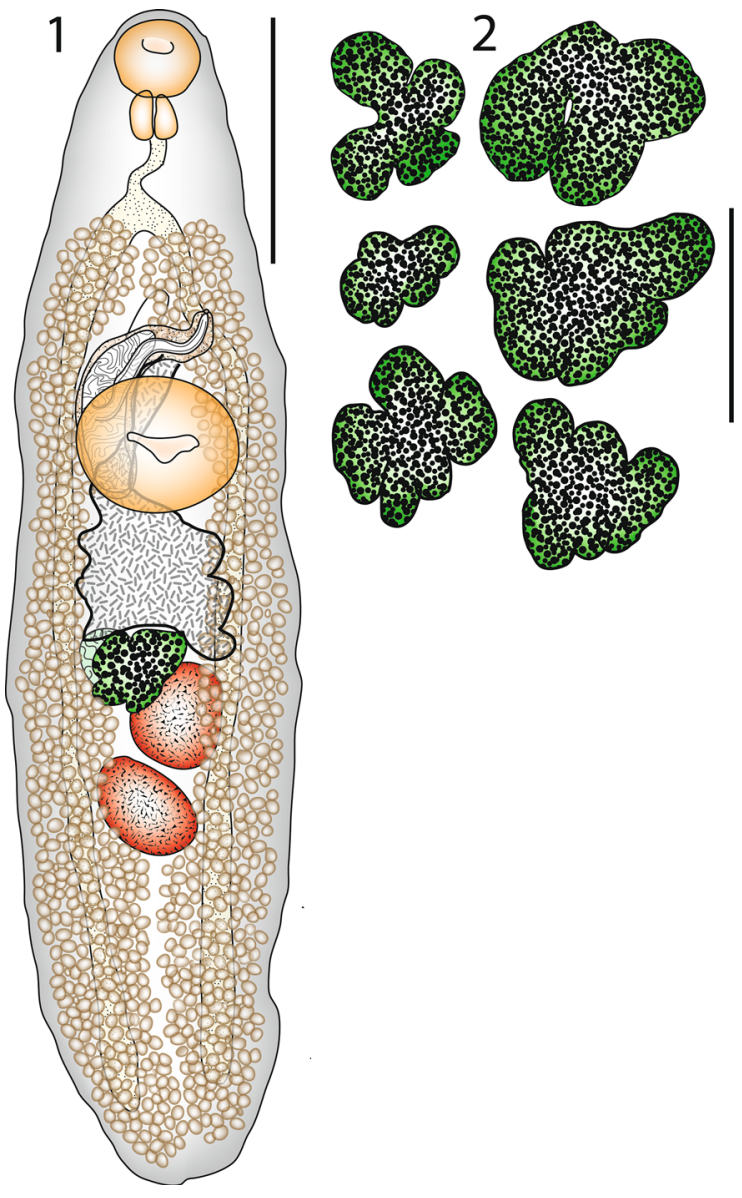

Figs. 1-2 Hamacreadium cribbi n. sp. 1, Holotype in ventral view, with uterus outline in bold; 2, Outline drawing of six ovaries to show examples of the variation in lobation. Scalebars: $1,1,000 \mu \mathrm{m} ; 2,500 \mu \mathrm{m}$

occasionally very slightly into hindbody, may be restricted to forebody in flattened specimens. Seminal vesicle long, coiled in posterior part of cirrus-sac. Pars prostatica and ejaculatory duct not clearly differentiated, long, coiled, complex coiling distally. Genital atrium distinct. Genital pore sinistral, ventral to left caeca or close, about halfway between bifurcation and ventral sucker.

Ovary usually lobate (3-5 lobes; see Fig. 2), oblique to and overlapping anterior testis. Seminal receptacle oval, dorsal to ovary. Mehlis' gland preovarian. Laurer's canal opens dorsally to Mehlis' gland. Uterus pre-ovarian, mainly intercaecal. Eggs tanned, operculate. Metraterm thick-walled, reaches level of ventral sucker. Vitellarium follicular, fields reach from bifurcal level of ventral sucker, to close to 
Table 1 Measurements (in $\mu \mathrm{m}$ ) and ratios of type-series of Hamacreadium cribbi $\mathrm{n}$. sp. ex Lethrinus miniatus $(\mathrm{n}=25)$

\begin{tabular}{|c|c|c|c|}
\hline Feature & Minimum & Maximum & Mean \\
\hline Body length (BL) & 3,049 & 5,747 & 4,585 \\
\hline Body width & 766 & 1,529 & 1,150 \\
\hline Forebody length & 1,138 & 1,935 & 1,517 \\
\hline Pre-oral lobe length & 0 & 53 & 23 \\
\hline Oral sucker length & 240 & 382 & 315 \\
\hline Oral sucker width & 239 & 417 & 331 \\
\hline Prepharynx length & 0 & 19 & 4 \\
\hline Pharynx length & 140 & 298 & 212 \\
\hline Pharynx width & 150 & 286 & 207 \\
\hline Oesophagus length & 184 & 441 & 277 \\
\hline Intestinal bifurcation to ventral sucker & 530 & 1,128 & 826 \\
\hline Vitellarium to ventral sucker & 478 & 1,099 & 736 \\
\hline Ventral sucker length & 427 & 690 & 586 \\
\hline Ventral sucker width & 450 & 722 & 608 \\
\hline Cirrus-sac length & 597 & 1,198 & 954 \\
\hline Cirrus-sac width & 125 & 235 & 192 \\
\hline Ventral sucker to ovary & 98 & 468 & 311 \\
\hline Ovary length & 200 & 424 & 327 \\
\hline Ovary width & 237 & 541 & 386 \\
\hline Ovary to anterior testis & 0 & 2 & 0 \\
\hline Anterior testis length & 301 & 622 & 445 \\
\hline Anterior testis width & 263 & 573 & 425 \\
\hline Distance between testes & 0 & 10 & 1 \\
\hline Posterior testis length & 281 & 687 & 485 \\
\hline Posterior testis width & 286 & 630 & 456 \\
\hline Post-testicular region & 592 & 1,600 & 1,196 \\
\hline Post-caecal distance & 84 & 373 & 201 \\
\hline Egg length & 72 & 93 & 84 \\
\hline Egg width & 38 & 56 & 48 \\
\hline Body width as $\%$ of $\mathrm{BL}$ & 20.9 & 28.8 & 25.1 \\
\hline Forebody as $\%$ of $\mathrm{BL}$ & 30.4 & 37.5 & 33.3 \\
\hline Sucker length ratio & $1: 1.53$ & $1: 2.27$ & $1: 1.87$ \\
\hline Sucker width ratio & $1: 1.69$ & $1: 2.18$ & $1: 1.84$ \\
\hline Oral sucker: pharynx ratio & $1: 1.23$ & $1: 1.82$ & $1: 1.61$ \\
\hline Ventral sucker to ovary as $\%$ of $\mathrm{BL}$ & 3.23 & 9.57 & 6.68 \\
\hline Post-testicular region as $\%$ of $\mathrm{BL}$ & 19.4 & 31.6 & 25.8 \\
\hline Oesophagus as \% of BL & 4.19 & 9.17 & 6.10 \\
\hline Intestinal bifurcation to ventral sucker as $\%$ of BL & 15.1 & 23.0 & 18.0 \\
\hline Vitellarium to ventral sucker as $\%$ of BL & 11.5 & 20.4 & 16.1 \\
\hline Ovary to anterior testis as \% of $\mathrm{BL}$ & 0 & 0.04 & 0 \\
\hline Distance between testes as $\%$ of $\mathrm{BL}$ & 0 & 0.21 & 0.02 \\
\hline
\end{tabular}


posterior extremity, lateral to caeca and encroaching slightly over dorsal and ventral surface of caeca, almost confluent in bifurcal and post-testicular regions, usually continuous at level of ventral sucker, occasionally interrupted on one or both sides.

Excretory pore terminal. Vesicle I-shaped, reaches to about level of genital pore.

\section{Variation}

The variation seen in our specimens covers some of the features previously used to distinguish species of Hamacreadium:

- Vitellarium anterior extent: At level of intestinal bifurcation: 52 specimens (58\%); distinctly postbifurcal, but not to ventral sucker: 38 specimens $(42 \%)$.

- Vitellarium interruptions at ventral sucker level: Continuous, no interruption: 73 specimens (81\%); interruptions both sides: 7 specimens $(8 \%)$; interruptions one side: 9 specimens (10\%).

- Cirrus-sac reach (continuum): To about mid ventral sucker level: 49 specimens (54\%); to posterior part of ventral sucker, occasionally very slightly into hindbody: 41 specimens (46\%).

- Ovary lobation. Not always clear, sub-lobes complicate the picture: Three lobes: 69 specimens (77\%); four lobes: 15 specimens (17\%); Five lobes: 6 specimens $(7 \%)$.

\section{Discussion}

This species was reported from this host species by (Justine et al., 2010b) under the name Neolebouria sp. A. These authors also reported the following species as hosts: the Spotcheek Emperor Lethrinus rubrioperculatus Sato; the Pacific Yellowtail Emperor Lethrinus atkinsoni Seale, the Drab Emperor Lethrinus ravus Carpenter \& Randall, and the Slender Emperor, Lethrinus variegatus Valenciennes. This description is based solely on the worms from L. miniatus, and it is to be noticed that worms from the other hosts may differ, possibly at the specific level. The eggs are consistently larger in the specimens from L. miniatus than in any of the other hosts, or indeed any of the other similar species discussed below (Fig. 3). The worms from Lethrinus atkinsoni are consistently broader (Fig. 4), and the relative distance between the ventral sucker and the ovary is greater (Fig. 5).

Several species of Hamacreadium have been reported from Lethrinus spp., including two reports from L. miniatus. Unfortunately, neither is accompanied by descriptions. Durio \& Manter (1968) reported the type-species of Hamacreadium, H. mutabile, from L. miniatus from New Caledonia, but molecular evidence and other evidence (see below) suggests that this species occurs only in lutjanid fishes. Shen (1985) reported H. lethrini Yamaguti, 1934 from L. miniatus from off the Xisha Islands (or Paracel Islands) in the South China Sea. These species will be discussed below, along with the other Hamacreadium spp. from Lethrinus spp.

\section{Hamacreadium balistesi Nagaty \& Abdel Aal,} 1962 was originally reported from the Spangled Emperor Lethrinus nebulosus (Forsskål) and the White-banded Triggerfish Rhinecanthus aculeatus (Linnaeus) (Balistidae) from the Red Sea (Nagaty \& Abdel Aal, 1962b) and was considered as synonym of H. mutabile by Bray \& Cribb (1989). As is discussed below, $H$. mutabile is probably a specific parasite of lutjanids. The cirrus-sac in H. balistesi is said to be 'preacetabular'. Nagaty \& Abdel Aal (1962b) mention that the vitelline fields 'may be interrupted at acetabular level' and differentiate it from $H$. interruptus by, inter alia, 'vitelline follicles constantly arranged or may be interrupted at acetabular level instead of their constant interrupted arrangement', but see the Fischthal \& Kuntz (1965) description of H. interruptus Nagaty, 1941 (discussed below). Ramadan (1983) considered $H$. balistesi a synonym of $H$. interruptus. The ventral sucker to ovary distance is relatively distinctly greater than in $H$. cribbi n. sp. (Fig. 5) and the eggs are smaller (Fig. 3). The excretory system is neither described nor illustrated.

2. Hamacreadium diacopae Nagaty \& Abdel Aal, 1962 was originally reported from the Dory Snapper Lutjanus fulviflamma (Forsskål) (Lutjanidae) from the Red Sea (Nagaty \& Abdel Aal, 1962a) and later from the 'bec de cane' Lethrinus sp. (most probably $L$. nebulosus) from New Caledonia (Durio \& Manter, 1968). The only description was based on a single specimen. It is small, broad (width $42 \%$ of body length, BL), with a long forebody (49\% BL), the ventral sucker tends to be relatively larger [suckerwidth ratio $1: 1.83-2.00(1: 2.22)$ ], it has a short posttesticular region $(12 \% \mathrm{BL})$, the ovary overlaps the 


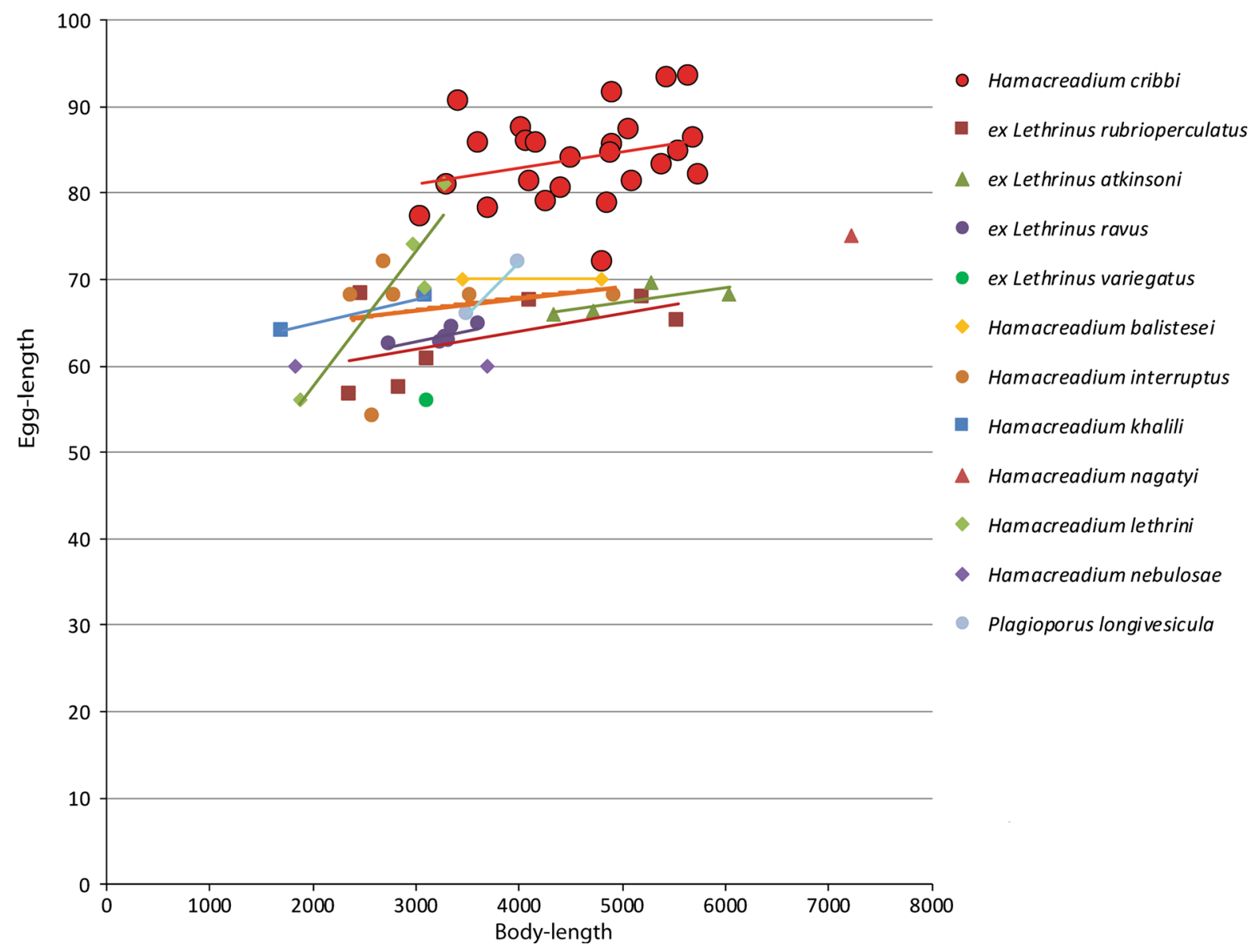

Fig. 3 Graph showing egg-length plotted against body-length of Hamacreadium cribbi n. sp., original measurements of other Hamacreadium-like worms from New Caledonian lethrinids and measurements of named species taken from the ranges given in the literature. Values on the $\mathrm{x}$ and $\mathrm{y}$ axes are in $\mu \mathrm{m}$

ventral sucker and the vitellarium reaches to the oesophagus. The excretory system is neither described nor illustrated.

\section{Hamacreadium egyptia el Abdou, Heckmann,} Beltagy \& Ashour, 2001 was described from Lethrinus nebulosus and the Sky Emperor Lethrinus mahsena (Forsskål) in the Red Sea (el Abdou et al., 2001). Although reported from two hosts, measurements of only one specimen are given and these measurements vary between the description and the table. The illustrations and the tiny gonads clearly show that the worm is immature and we consider it unrecognisable.

4. Hamacreadium epinepheli Yamaguti, 1934, now known as Cainocreadium epinepheli, is a widely reported parasite of Indo-Pacific serranids, including those from New Caledonian waters (Bray \& Justine, 2007; Justine et al., 2010a) and has been reported in the Chinese Emperor Lethrinus haematopterus Temminck \& Schlegel, off Japan by Yamaguti (1934). Nagaty (1941) considered $H$. epinepheli a synonym of $H$. mutabile, which he reported from serranids, lethrinids and lutjanids, but later (Nagaty, 1956), recognised the species as distinct. Shen (1985) recorded Cainocreadium epinepheli in L. haematopterus, from off the Xisha Islands. The median genital pore distinguishes Cainocreadium from Hamacreadium.

5. Hamacreadium interruptus Nagaty, 1941 was originally reported from the Pink Ear Emperor Lethrinus lentjan (Lacépède) (as Lethrinus mahsenoides Valenciennes) from the Red Sea (Nagaty, 1941). Fischthal \& Kuntz (1965) recorded H. interruptus from the Smalltooth Emperor Lethrinus microdon Valenciennes and the Asian Swamp Eel Monopterus albus (Zuiew) (Synbranchidae) off Jesselton, North Borneo. 


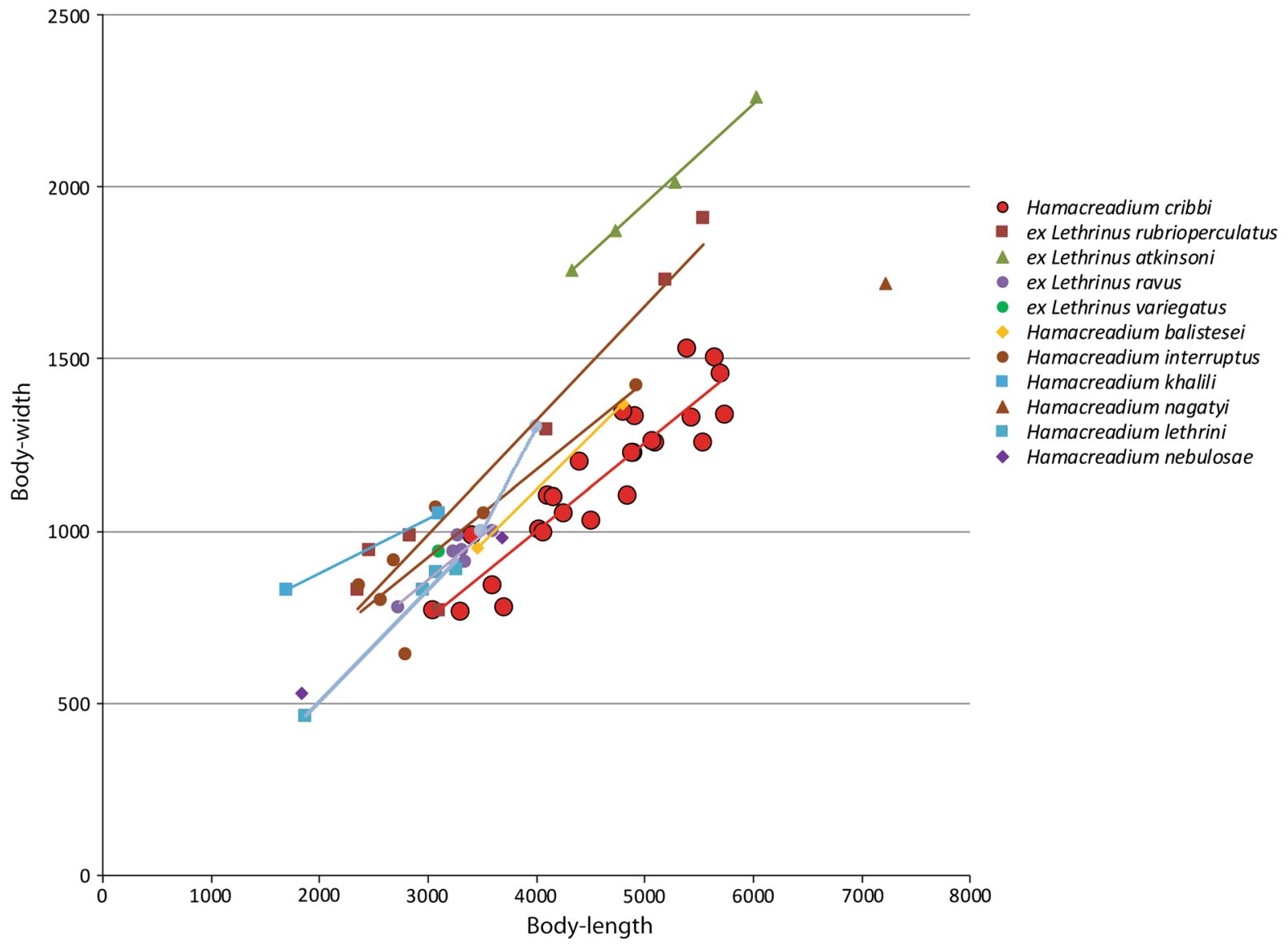

Fig. 4 Graph showing body-width plotted against body-length of Hamacreadium cribbi n. sp., original measurements of other Hamacreadium-like worms from New Caledonian lethrinids and measurements of named species taken from the ranges given in the literature. Values on the $\mathrm{x}$ and $\mathrm{y}$ axes are in $\mu \mathrm{m}$

They considered Plagioporus longivesicula Yamaguti, 1952 and Hamacreadium lethrini Nagaty \& Abdel Aal, 1962 as synonyms. Hafeezullah \& Dutta (1980) described $H$. interruptus from an unidentified marine fish off Chiria Tapu, Andaman Islands. The lack of an identified host reduces the value of the description and it is not used in comparison here. Tadros et al. (1978) reported this species from the type-host also in the Red Sea. Nagaty (1941) described and illustrated a large lateral gap in the vitelline fields at the level of the ventral sucker. Fischthal \& Kuntz (1965) stated that the vitelline fields are interrupted at acetabular level on both sides in 12 , on left side only in 4 , on right side only in 1 , and uninterrupted on both sides in 3'. The eggs are smaller than those in $H$. cribbi n. sp. (Fig. 3). The excretory system is neither described nor illustrated.

6. Hamacreadium khalili Ramadan, 1983 was originally reported from L. mahsena and L. nebulosus from the Red Sea (Ramadan, 1983). El-Labadi et al. (2006) reported the species from the Lavender Jobfish Pristipomoides sieboldii (Bleeker) (Lutjanidae) and the Yellow-edged Lyretail Variola louti (Forsskål) (Serranidae), from the Gulf of Aqaba in the Red Sea, without descriptive matter. The species is differentiated from $H$. interruptus in a key by 'Testes globular and lobulated, cirrus pouch triangular'. The vitelline follicles are 'aggregated in two sets, a posterior and an anterior, with a gap between them'. The eggs are smaller than those in $H$. cribbi n. sp. (Fig. 3). The anterior extent of the excretory vesicle was not traced.

7. Hamacreadium koshari Nagaty \& Abdel Aal, 1962, originally reported in Serranus sp. (Serranidae) and Lethrinus mahsena from the Red Sea (Nagaty \& Abdel Aal, 1962b), has vitelline fields restricted to the hindbody and Bray \& Cribb (1989) considered it likely that it belongs on the genus Apopodocotyle Pritchard, 


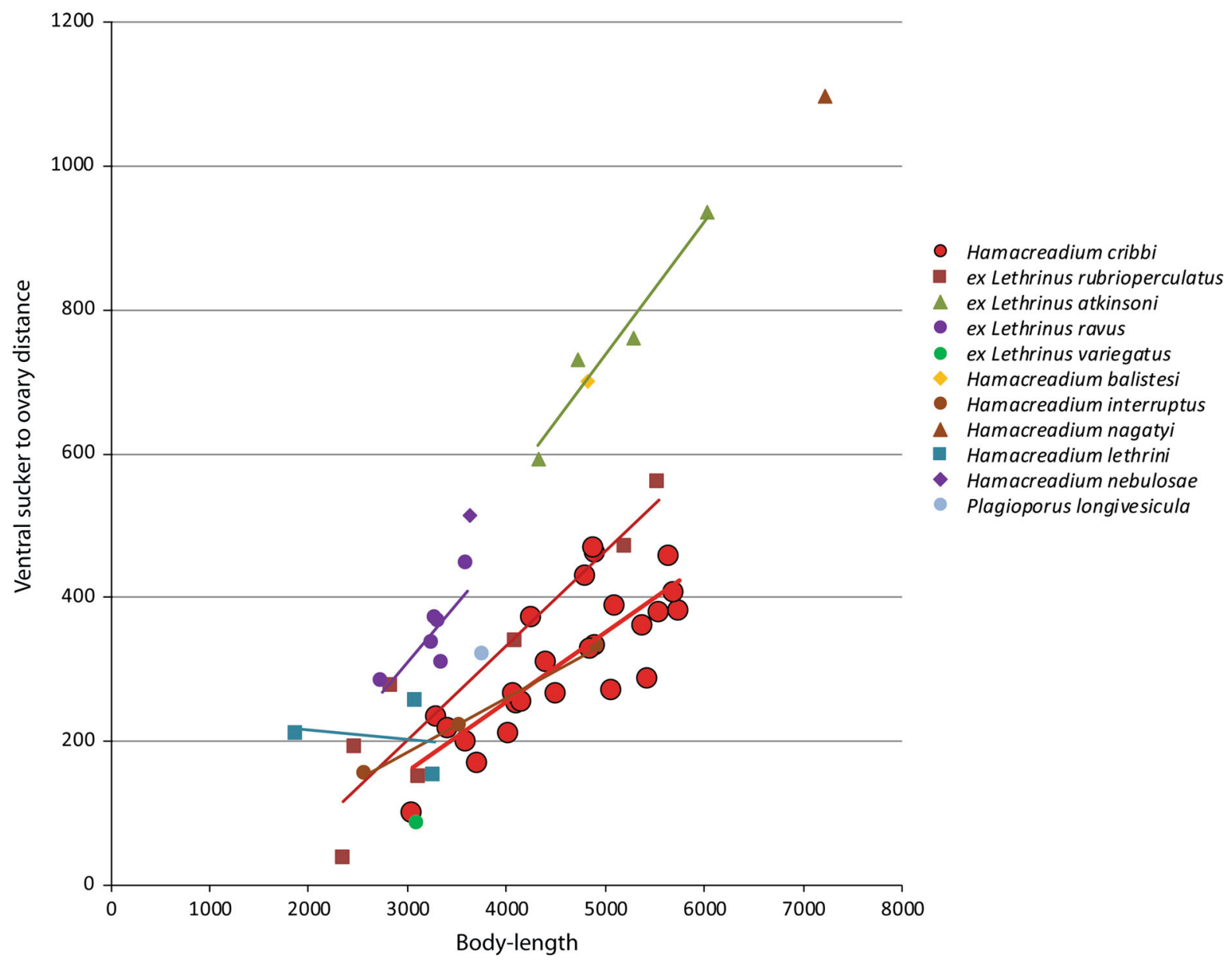

Fig. 5 Graph showing ventral sucker to ovary distance plotted against body-length of Hamacreadium cribbi n. sp., original measurements of other Hamacreadium-like worms from New Caledonian lethrinids and measurements of named species taken from illustrations in the literature. Values on the $\mathrm{x}$ and $\mathrm{y}$ axes are in $\mu \mathrm{m}$

1966, now considered a synonym of Cainocreadium Nicoll, 1947 (see Cribb, 2005).

8. Hamacreadium krusadaiensis Gupta, 1956 was originally reported from a 'marine cat-fish' from the Gulf of Mannar (Gupta, 1956). Hafeezullah (1971) redescribed the species from Lethrinus nebulosus (syn. L. frenatus Valenciennes) from the Gulf of Mannar off Tuticorin. Gibson (1976) transferred the species to Neolebouria Gibson, 1976 and it has been included in the two most recent keys to that genus (Bray \& Justine, 2009; Dronen et al., 2014).

\section{Hamacreadium nagatyi Lamothe Argumedo,} 1962 (syns H. lethrini Nagaty \& Abdel Aal, 1962 nec Yamaguti, 1934; H. lenthrium Manter, 1963) is based on a single large specimen from Lethrinus lentjan (as Lethrinus mahsenoides) from the Red Sea (Nagaty \&
Abdel Aal, 1962a). As the name is pre-occupied, it has been replaced twice, by Lamothe-Argumedo (1962) and Manter (1963). At 7,220 $\mu \mathrm{m}$ long, this species is larger than any other reported lethrinid Hamacreadium. Cirrus-sac is entirely within the forebody. The ventral sucker to ovary distance is relatively distinctly greater than in H. cribbi n. sp. (Fig. 5) and the eggs tend to be smaller (Fig. 3). The excretory system is neither described nor illustrated.

10. Hamacreadium lethrini Yamaguti, 1934, was originally reported from Lethrinus haematopterus, from the Pacific coast of Wakayama Prefecture, Japan (Yamaguti, 1934). Fischthal \& Kuntz (1964) redescribed, but did not illustrate, the species from the Longfin Emperor Lethrinus erythropterus Valenciennes (as Lethrinus hypselopterus Bleeker) and the 
Humpback Red Snapper Lutjanus gibbus (Forsskål) (Lutjanidae) from Puerto Princesa, Palawan Island. Philippines. The species has been reported two further times, but with no descriptive matter. Dyer et al. (1988) reported as host the Thumbprint Emperor Lethrinus harak (Forsskål) from Okinawa, Japan and Shen (1985) reported Lethrinus miniatus and the Grey Large-eye Bream Gymnocranius griseus (Temminck \& Schlegel) (Lethrinidae) as hosts off Xisha Islands (or Paracel Islands) in the South China Sea. The original description is very similar to $H$. cribbi n. sp., but the testes are described and illustrated as irregularly indented, not the usual condition in $\mathrm{H}$. cribbi. Fischthal \& Kuntz (1964) described the post-testicular distance as $0-585 \mu \mathrm{m}$, indicating that at least one of their specimens was damaged. The eggs are generally smaller than in H. cribbi (Fig. 3). The excretory system reaches to about the same level as in $H$. cribbi.

11. Hamacreadium mehsena Nagaty, 1941, reported from Lethrinus 'mehsena' (presumably Lethrinus mahsena) from the Red Sea (Nagaty, 1941) differs from Hamacreadium in that the vitellarium does not reach into the forebody. Pritchard (1966) placed the species in her new genus Apopodocotyle Pritchard, 1966, but Cribb (2005) replaced in its original genus. It appears closest to the genus Podocotyle Dujardin, 1845, but while the testes are described as oblique, they appear almost symmetrical in the illustration. This form cannot be confused with $H$. cribbi. The excretory system is neither described nor illustrated.

12. Hamacreadium mutabile Linton, 1910, was originally described from the Grey Snapper Lutjanus griseus (Linnaeus) (considered the type-host), the Schoolmaster Snapper Lutjanus apodus (Walbaum), the Yellowtail Snapper Ocyurus chrysurus (Bloch) (all Lutjanidae), the Porkfish Anisotremus virginicus (Linnaeus) (Haemulidae) and the Gray Angelfish Pomacanthus arcuatus (Linnaeus) (Pomacanthidae) from the Dry Tortugas, Florida, USA, in the Gulf of Mexico (Linton, 1910). Since then it has been reported from an unfeasible number of host-species and localities, including several lethrinids. Bray \& Cribb (1989) presented a long list of putative new synonyms, including Hamacreadium balistesi, Hamacreadium interruptum, Hamacreadium lenthrium, Hamacreadium lethrini Yamaguti, 1934 nec Nagaty \& Abdel Aal, 1962, Hamacreadium lethrini Nagaty \& Abdel Aal, 1962 nec Yamaguti, 1934, Hamacreadium nagatyi, Hamacreadium nebulosae and Plagioporus longivesicula. The advent of molecular techniques has cast doubt on the likelihood of one species having such a wide host and locality range. Miller et al. (2011) having examined the host-specificity of fish digeneans on the Great Barrier Reef, concluded 'that no euryxenous host distribution should be accepted on the basis of morphology only'. It is worth noting that McCoy $(1929,1930)$ was able to experimentally infect only lutjanids with $H$. mutabile despite the 'numerous other species tested'. Recently, Andres et al. (2014) have registered rDNA sequence data on $H$. mutabile from $L$. griseus, from the northern Gulf of Mexico, which differs distinctly from that of $H$. cribbi (Fig. 6). Hamacreadium mutabile has been reported in lutjanids in New Caledonian waters (Justine et al., 2012b).

13. Hamacreadium nebulosae Nagaty \& Abdel Aal, 1962 is known only from three specimens found in L. nebulosus in the Red Sea (Nagaty \& Abdel Aal, 1962b). According to the measurements given the sucker-width ratio is about $1: 1$, whereas in the illustration this ratio is about $1: 1.8$. The excretory vesicle is said to reach to the mid-level of the ventral sucker. The eggs are distinctly smaller than those of H. cribbi (Fig. 3).

14. Plagioporus (Plagioporus) longivesicula Yamaguti, 1952 is known from two gravid and three immature specimens from Lethrinus sp., off Makassar, southern Sulawesi (Yamaguti, 1952). Fischthal \& Kuntz (1965) considered Plagioporus longivesicula a synonym of Hamacreadium interruptus and Bray \& Cribb (1989) went further and listed it as a synonym of H. mutabile. The excretory vesicle reaches into the pre-bifurcal region. The eggs are distinctly smaller than those in H. cribbi (Fig. 3).

Molecular phylogeny

The description of this species was considered desirable as it is included in a wider study of opecoelid

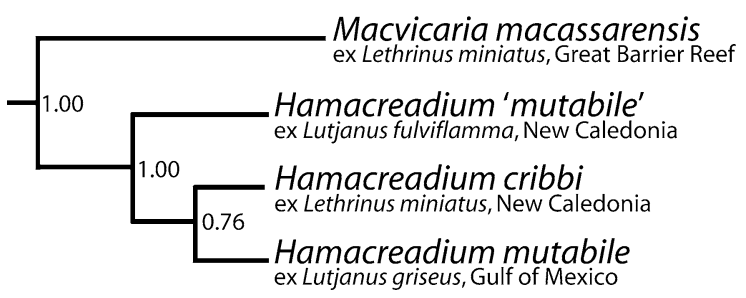

Fig. 6 Extract from a Bayesian inference LSU + SSU rDNA tree showing the relationships of the putative Hamacreadium operational taxonomic units (OTUs) 
phylogeny and systematics based on LSU and SSU rDNA sequences. A small section of the resultant tree is included here as Figure 6 and details of the techniques are as in Bray et al. (2016). Hamacreadium mutabile is a widely reported parasite mainly of lutjanid fishes, and our worms from a lutjanid from New Caledonia, labelled as Hamacreadium 'mutabile', were identified as this species by Justine et al. (2012b). Morphologically this New Caledonian form appears practically identical to the Gulf of Mexico form, but the molecular evidence indicates that it is one of a group as closely related, but distinct, worms (Fig. 6). The Gulf of Mexico H. mutabile material (based only on a LSU rDNA sequence) is from the type-host in the eastern Gulf of Mexico, close to the type-locality of Dry Tortugas, Florida (Linton, 1910; Andres et al., 2014). Hamacreadium cribbi clusters weakly with $H$. mutabile, it is probably more realistic to consider the Hamacreadium species to be related by a polytomy.

Acknowledgements Our thanks are due to the many students who were involved in the collection of lethrinid parasites and are listed in Justine et al. (2010b).

Funding The generation of sequences was funded by a Life Sciences Molecular Taxonomic Support grant from the Natural History Museum, London.

\section{Compliance with ethical standards}

Conflict of interest The authors declare that they have no conflict of interest.

Ethical approval All applicable institutional, national and international guidelines for the care and use of animals were followed. Annual permits for collecting fish and parasites were issued by Province Sud, New Caledonia, to IRD, from 2003 to 2010 .

Open Access This article is distributed under the terms of the Creative Commons Attribution 4.0 International License (http:// creativecommons.org/licenses/by/4.0/), which permits unrestricted use, distribution, and reproduction in any medium, provided you give appropriate credit to the original author(s) and the source, provide a link to the Creative Commons license, and indicate if changes were made.

\section{References}

Andres, M. J., Pulis, E. E., \& Overstreet, R. M. (2014). New genus of opecoelid trematode from Pristipomoides aquilonaris (Perciformes: Lutjanidae) and its phylogenetic affinity within the family Opecoelidae. Folia Parasitologica, 61, 223-230.

Bray, R. A., \& Cribb, T. H. (1989). Digeneans of the family Opecoelidae Ozaki, 1925 from the southern Great Barrier Reef, including a new genus and three new species. Journal of Natural History, 23, 429-473.

Bray, R. A., Cribb, T. H., Littlewood, D. T. J., \& Waeschenbach, A. (2016). The molecular phylogeny of the digenean family Opecoelidae Ozaki, 1925 and the value of morphological characters, with the erection of a new subfamily. Folia Parasitologica, 63(013), 1-11.

Bray, R. A., \& Justine, J.-L. (2007). Pseudopycnadena tendu sp. nov. (Digenea, Opecoelidae) in the yellow-spotted triggerfish Pseudobalistes fuscus (Perciformes, Balistidae) and additional opecoelids parasitizing fishes from the waters off New Caledonia. Acta Parasitologica, 52, 13-17.

Bray, R. A., \& Justine, J.-L. (2009). Opecoelids (Platyhelminthes: Digenea) from the fork-tailed threadfin bream Nemipterus furcosus (Valenciennes, 1830) (Perciformes: Nemipteridae), with preliminary keys to the problematic genera Macvicaria Gibson \& Bray, 1982 and Neolebouria Gibson, 1976. Acta Parasitologica, 54, 218-229.

Cribb, T. H. (2005). Family Opecoelidae Ozaki, 1925. In: Jones, A., Bray, R. A. \& Gibson, D. I. (Eds), Keys to the Trematoda. Volume 2. Wallingford: CABI Publishing and the Natural History Museum, pp. 443-531.

Cribb, T. H., \& Bray, R. A. (2010). Gut wash, body soak, blender, and heat-fixation: Approaches to the effective collection, fixation and preservation of trematodes of fishes. Systematic Parasitology, 55, 45-52.

Dronen, N. O., Blend, C. K., Ostrowski de Núñez, M. C., Malhotra, S. K., \& Jaiswal, N. (2014). Keys to the species of Neolebouria Gibson, 1976 (Digenea: Opecoelidae: Plagioporinae), with a redescription of Neolebouria truncata (Linton, 1940). Systematic Parasitology, 88, 213-225.

Durio, W. O., \& Manter, H. W. (1968). Some digenetic trematodes of marine fishes of New Caledonia. Part II. Opecoelidae and Lepocreadiidae. Journal of Parasitology, 54, 747-756.

Dyer, W. G., Williams, E. H, Jr., \& Williams, L. B. (1988). Digenetic trematodes of marine fishes of Okinawa, Japan. Journal of Parasitology, 74, 638-645.

El-Labadi, S. N., Ismail, N. S., \& Khalaf, M. (2006). Intestinal digenetic trematodes of some fishes from the Gulf of Aqaba, Red Sea. Pakistan Journal of Zoology, 38, 43-48.

El Abdou, N., Heckmann, R. A., Beltagy, S. M., \& Ashour, A. A. (2001). Pseudoplagioporus interruptus Durio and Manter, 1968 and Hamacreadium agyptia [sic] sp. n. (Trematoda: Opecoeliidae) from the Red Sea Fish in Egypt. Journal of King Abdulaziz University Marine Sciences, 12(Special Issue), 175-188.

Fischthal, J. H., \& Kuntz, R. E. (1964). Digenetic trematodes of fishes from Palawan Island, Philippines. Part II. Five Opecoelidae, including three new species. Proceedings of the Helminthological Society of Washington, 31, 40-46.

Fischthal, J. H., \& Kuntz, R. E. (1965). Digenetic trematodes of fishes from North Borneo (Malaysia). Proceedings of the Helminthological Society of Washington, 32, 63-71.

Gibson, D. I. (1976). Monogenea and Digenea from fishes. Discovery Reports, 36, 182-266. 
Gupta, N. K. (1956). Studies on the digenetic trematodes of marine fishes from the Gulf of Mannar (India). Research Bulletin of the Panjab University of Science (Zoology), 89, 61-83.

Hafeezullah, M. (1971). Opecoelid trematodes of marine fishes of India. Parasitology, 62, 321-329.

Hafeezullah, M., \& Dutta, I. B. (1980). Digenetic trematodes of marine fishes of Andaman. Records of the Zoological Survey of India, 77, 75-82.

Justine, J.-L., Beveridge, I., Boxshall, G. A., Bray, R. A., Moravec, F., Trilles, J.-P., et al. (2010a). Parasite biodiversity in coral reef fish: An annotated list of parasites (Isopoda, Copepoda, Monogenea, Digenea, Cestoda and Nematoda) collected in groupers (Serranidae, Epinephelinae) in New Caledonia. Folia Parasitologica, 57, 237-262.

Justine, J.-L., Beveridge, I., Boxshall, G. A., Bray, R. A., Moravec, F., \& Whittington, I. D. (2010b). An annotated list of fish parasites (Copepoda, Monogenea, Digenea, Cestoda and Nematoda) collected from Emperors and Emperor Bream (Lethrinidae) in New Caledonia further highlights parasite biodiversity estimates on coral reef fish. Zootaxa, 2691, 1-40.

Justine, J.-L., Briand, M. J., \& Bray, R. A. (2012a). A quick and simple method, usable in the field, for collecting parasites in suitable condition for both morphological and molecular studies. Parasitology Research, 111, 341-351.

Justine, J. L., Beveridge, I., Boxshall, G. A., Bray, R. A., Miller, T. L., Moravec, F., et al. (2012b). An annotated list of fish parasites (Isopoda, Copepoda, Monogenea, Digenea, Cestoda, Nematoda) collected from Snappers and Bream (Lutjanidae, Nemipteridae, Caesionidae) in New Caledonia confirms high parasite biodiversity on coral reef fish. Aquatic Biosystems, 8, 1-22.

Lamothe-Argumedo, R. (1962). Redescripcion de dos trematodos digeneos de peces del Pacifico Mexicano. Anales del Instituto de Biología. Universidad de México, 33, 97-111.

Linton, E. (1910). Helminth fauna of the Dry Tortugas. II. Trematodes. Papers from the Tortugas Laboratory of the Carnegie Institute of Washington, 4, 11-98.

Manter, H. W. (1963). Studies on digenetic trematodes of fishes of Fiji. II. Families Lepocreadiidae, Opistholebetidae, and Opecoelidae. Journal of Parasitology, 49, 99-113.

McCoy, O. R. (1929). The life-history of a marine trematode, Hamacreadium mutabile Linton, 1910. Parasitology, 21, 220-225.
McCoy, O. R. (1930). Experimental studies on two fish trematodes of the genus Hamacreadium (Family Allocreadiidae). Journal of Parasitology, 17, 1-13.

Miller, T. L., Bray, R. A., \& Cribb, T. H. (2011). Taxonomic approaches to and interpretation of host specificity of trematodes of fishes: Lessons from the Great Barrier Reef. Parasitology, 138, 1710-1722.

Nagaty, H. F. (1941). Trematodes of fishes from the Red Sea. Part 2. The genus Hamacreadium Linton, 1910 (Fam. Allocreadiidae) with a description of two new species. Journal of the Egyptian Medical Association, 24, 300-310.

Nagaty, H. F. (1956). Trematodes of fishes from the Red Sea. Part 7. On two gyliauchenids and three allocreadoids, including four new species. Journal of Parasitology, 42, 523-527.

Nagaty, H. F., \& Abdel Aal, T. M. (1962a). Trematodes of fishes from the Red Sea. Part 15. Four new species of $\mathrm{Ha}$ macreadium family Allocreadiidae. Journal of Parasitology, 48, 384-386.

Nagaty, H. F., \& Abdel Aal, T. M. (1962b). Trematodes of fishes from the Red Sea. Part 16. On three new species of $\mathrm{Ha}$ macreadium (family: Allocreadiidae). Journal of the Arab Veterinary and Medical Association, 22, 301-305.

Pritchard, M. H. (1966). A revision of the genus Podocotyle (Trematoda: Opecoelidae). Zoologische Jahrbücher. Abteilung für Systematik, Ökologie und Geographie der Tiere, 93, 158-172.

Ramadan, M. M. (1983). A review of the trematode genus Hamacreadium Linton, 1910 (Opecoelidae), with descriptions of two new species from the Red Sea fishes. Japanese Journal of Parasitology, 32, 531-539.

Shen, J.-W. (1985). Digenetic trematodes of fishes from the Xisha Islands, II. Studia Marina Sinica, 24, 167-180 (In Chinese).

Tadros, G., Iskandar, A. R., \& Wassef, N. A. (1978). On some intestinal trematodes from the Nile and Red Sea fishes with a histopathologic study of their habitat. Journal of the Egyptian Society of Parasitology, 8, 383-392.

Yamaguti, S. (1934). Studies on the helminth fauna of Japan. Part 2. Trematodes of fishes, I. Japanese Journal of Zoology, 5, 249-541.

Yamaguti, S. (1952). Parasitic worms mainly from Celebes. Part 1. New digenetic trematodes of fishes. Acta Medicinae Okayama, 8, 146-198. 